\title{
NOTE ON DATING AND BIBLICAL CITATIONS
}

Throughout this book dates are given in the Old Style, based on the Julian calendar used in Russia from the reign of Tsar Peter I until January 1918. In the eighteenth century the Julian calendar lagged eleven days behind Europe's Gregorian calendar; in the nineteenth century, twelve days. Unless otherwise stated, the biblical passages cited throughout this book appear in Platon's writings and are therefore set off by single quotation marks within double quotation marks. In instances where Platon paraphrases or gives a partial biblical quote and I provide the exact wording or full passage, double quotation marks are used. In identifying Psalms I follow the numbering of the Septuagint, as used by Platon.

For English translation of biblical passages, I rely on the latest edition of The Orthodox Study Bible (St. Athanasius Academy of Orthodox Theology, 2008), hereafter OSB (2008). Old Testament scripture is taken from the St. Athanasius Academy Septuagint, copyright 2008 by St. Athanasius Academy of Orthodox Theology. Used by permission. All rights reserved. New Testament scripture is taken from the New King James Version, copyright 1982 by Thomas Nelson, Inc. Used by permission. All rights reserved. 
